\title{
Occurrence of the Megatoothed sharks (Lamniformes:Otodontidae) in Alabama, USA
}

The Otodontidae include some of the largest sharks to ever live in the world's oceans (i.e. Carcharocles megalodon). Here we report on Paleocene and Eocene occurrences of Otodus obliquus and Carcharocles auriculatus from Alabama, USA. Teeth of Otodus are rarely encountered in the Gulf Coastal Plain and this report is one of the first records for Alabama. Carcharocles auriculatus is more common in the Eocene deposits of Alabama, but its occurrence has been largely overlooked in the literature. We also refute the occurrence of the Oligocene Carcharocles angustidens in the state. Raised awareness and increased collecting of under-sampled geologic formations in Alabama will likely increase sample sizes of $O$. obliquus and $C$. auriculatus and also might unearth other otodontids, such as $C$. megalodon and C. chubutensis. 
1 Occurrence of the Megatoothed sharks (Lamniformes:Otodontidae) in Alabama, USA

2 Authors: Ehret, Dana J. ${ }^{1}$ and Ebersole, Jun ${ }^{2}$

3 'Alabama Museum of Natural History, PO Box 870340, Tuscaloosa, Alabama 35487-0340

4 Email: djehret@ua.edu

$5 \quad{ }^{2}$ McWane Science Center, $20019^{\text {th }}$ Street North, Birmingham, Alabama 35203

6 Email: jebersole@mcwane.org

7 Corresponding Author: Ehret, Dana J.

8 Alabama Museum of Natural History, PO Box 870340, Tuscaloosa, Alabama 35487-0340

9 Email: djehret@ua.edu 


\section{Geologic Setting}

In Alabama, Otodus obliquus and Carcharocles auriculatus specimens have been collected from lithostratigraphic units ranging from the early Paleocene to Middle Eocene including the Midway, Sabine, Claiborne, Jackson groups (Figs. 1 and 2, Table 1). The Paleocene and Eocene formations in the state make up a nearly time-continuous series that ranges from the $\mathrm{K} / \mathrm{Pg}$ contact to the Eocene/Oligocene contact (Raymond, 1988). A small unconformity exists between the upper-most Cretaceous units in the state, the Prairie Bluff Chalk and Providence Sand, and the lower-most Paleocene Clayton Formation. The Clayton Formation (which includes 
54 the Pine Barren and McBryde Limestone members) is the basal unit in the Midway Group, a

55 group that also includes, in ascending order, the Porters Creek (with the Matthews Landing Marl

56 Member) and Naheola (with the Oak Hill and Coal Bluff Marl members) formations. The

57 Midway Group is conformably overlain by the Paleocene/Eocene Wilcox Group. The Paleocene

58 units within the Wilcox Group include, in ascending order, the Nanafalia Formation (with the

59 Gravel Creek Sand Member, an informal unit referred locally as the "Ostrea thirsae beds," and

60 the Grampian Hills Member), and the Tuscahoma Sand (which includes the Greggs Landing Marl

61 and the Bells Landing Marl members).

62 The uppermost unit of the Wilcox Group is the Early Eocene (Ypresian) Hatchetigbee

63 Formation, which contains the Bashi Marl Member at its base. The Wilcox Group is

64 disconformably overlain by the lithostratigraphic units within the Claiborne and Jackson groups.

65 The Claiborne Group consists of, in ascending order, the Tallahatta and Lisbon (with informal

66 "lower," "middle," and "upper" members) formations, and the Gosport Sand. The Jackson Group

67 includes the Moodys Branch and Crystal River formations and the Yazoo Clay. The Yazoo Clay

68 in Alabama is further subdivided into the following chronologic members: the North Twistwood

69 Creek, Cocoa Sand, Pachuta Marl, and Shubuta (Fig. 2).

70

71

72

73

74

75

76

77

78

79

80

81

82

83

84

85

86

87

88

89

90

91

92

93

94

\section{SYSTEMATIC PALEONTOLOGY}

Class Chondrichthyes Huxley, 1880

Subclass Elasmobranchii Bonaparte, 1838

Order Lamniformes Berg, 1958

Family Otodontidae Glikman, 1964

Genus Otodus Agassiz, 1838

Otodus obliquus Agassiz, 1838

Figure 3A-D, Table 1

\section{Referred Specimens}

GSA CZ 5050, GSA CZ 5051, GSA CZ 5052, GSA CZ 5053, GSA CZ 5054

\section{Occurrence}

Wilcox County, Alabama

\section{Description}

Otodus obliquus teeth were identified using the following characteristics: triangular cusp, lacking serrations on cutting edges; labial face is moderately convex and does not overhang the root; lingual face is smooth and convex; a well developed v-shaped chevron on the lingual face; a pair of triangular cusplets that lack serrations; and a highly developed lingual protuberance of the root (Cappetta, 2012). Five O. obliquus specimens were identified in the historical collections housed at the Geological Survey of Alabama (GSA). GSA CZ 5051 (Fig. 3A) is part of the Schowalter Collection and was collected prior to 1889. Unfortunately the precise locality and formation of origin for GSA CZ 5051 is unknown as the specimen is only accompanied by a label marked "Tertiary, Wilcox," presumably referring to the Cenozoic strata in Wilcox County, Alabama. Of the Cenozoic units within this county, exposures can be found of all five Paleocene formations, which make up the Midway Group (Clayton, Porters Creek, and Naheola formations) and Wilcox Group (Nanafalia Formation and Tuscahoma Sand) in Alabama. Wilcox County also 
95

96

97

98

99

100

101

102

103

104

105

106

107

108

109

110

111

112

113

114

115

116

117

118

119

120

121

122

123

124

125

126

127

128

129

130

131

132

133

134

135

136

137

138

139

has exposures of the Ypresian Hatchetigbee Formation, also part of the Wilcox Group (Fig. 1). Based on the surface exposures of these formations, we argue this specimen is either Selandian (Naheola Formation) or Thanetian (Tuscahoma Sand) in age. The tooth is a nearly complete posterolateral that exhibits large triangular cusplets, with a secondary pair also present. GSA CZ 5051 also exhibits a v-shaped chevron on its lingual surface, and smooth cutting edges on the main cusp. Although the tip is broken, the measured main crown height is $25.5 \mathrm{~mm}$, while its width is $17.9 \mathrm{~mm}$.

GSA CZ 5050 (Fig. 3B) represents a right posterolateral tooth that is accompanied with a label inscribed "Sucarnoochee, Clarence Jones' Place." The term "Sucarnoochee" refers to the Sucarnoochee beds, a historical and informal unit that was described as being between the Paleocene Clayton and the Naheola formations. "Clarence Jones' Place" refers to a historic locality located near Camden in Wilcox County that is known for its fine exposures of the Matthews Landing Marl, which is the upper member of the Porters Creek Formation (Smith and Johnson, 1887). This member falls within the Morozovella angulata planktonic foraminiferal zone, placing it within the early Thanetian (Mancini and Tew, 1988). The tooth is fairly worn, and it is missing the distal cusplet as well as portions of the root. The main crown is $22.6 \mathrm{~mm}$ high and $16.0 \mathrm{~mm}$ wide and it does display a prominent $\mathrm{v}$-shaped chevron, making the identification possible.

GSA CZ 5052 (Fig. 3C) was found in the GSA collections with a label inscribed "Naheola, Matthews Landing, Alabama River", referring to the Naheola Formation and the historic locality Matthews Landing which is located along the Alabama River in Wilcox County. The listed formation, however, is likely an error as this locality represents the type section for the Matthews Landing Marl Member, which is the uppermost unit of the Porters Creek Formation. This member underlies the Naheola Formation, but in historical usage, the Matthews Landing Marl was incorrectly thought to be a member of the Naheola Formation (see Keroher et al., 1966). Therefore, the specimen can be referred to the very latest Danian or earliest Selandian. GSA CZ 5052 represents an anterior tooth, based on the symmetry of the main cusp. The tooth displays well-developed cusplets, a $v$-shaped chevron, smooth cutting edges, and a pronounced lingual protuberance of the root. The apex of the crown is chipped, but the remaining portion measures $29.8 \mathrm{~mm}$ in height and is $14.3 \mathrm{~mm}$ wide.

GSA CZ 5053 (Fig. 3D) is listed as coming from "Grave Yard Hill No. 4" in Wilcox County. Graveyard Hill is another important historic locality in eastern Wilcox County that contains a fossil zone located at the top of the Porters Creek Formation, making the specimen latest Danian or earliest Selandian (Toulmin, 1977). The specimen represents an anterior or first posterolateral tooth, with a crown height of $31.0 \mathrm{~mm}$ and a crown width of $18.8 \mathrm{~mm}$. GSA CZ 5053 is worn, likely from being exposed for a long period of time, but exhibits a pronounced lingual protuberance, v-shaped chevron, and has well developed cusplets.

The final O. obliquus specimen found in collections is GSA CZ 5054 (Fig. 3E). The label associated with this specimen states: "State Collection Midway Group". Although the exact locality for this specimen is unknown, the label indicates that it was discovered within the strata of the Midway Group. This lower to middle Paleocene group includes the Clayton, Porters Creek, and Naheola formations, meaning the tooth is either latest Danian or Selandian. This specimen is highly worn, missing the apex of the crown, cusplets, and most of the root. However, it does preserve the v-shaped chevron, which is diagnostic for the Otodontidae. The remaining portion of the crown is $18.4 \mathrm{~mm}$ in height and $19.1 \mathrm{~mm}$ wide. 
140

141

142

143

144

145

146

147

148

149

150

151

152

153

154

155

156

157

158

159

160

161

162

163

164

165

166

167

168

169

170

171

172

173

174

175

176

177

178

179

180

181

182

\section{Remarks}

The taxonomic assignment of the Otodontidae is a contentious subject that has been debated for over a century (Agassiz, 1843; Jordan and Hannibal, 1923; Glikman, 1964; Cappetta, 1987, 2012; Applegate and Espinosa-Arrubarrena, 1996; Zhelezko and Kozlov, 1999; Purdy et al., 2001; Nyberg et al., 2006; Pimiento et al., 2010, 2013; Ehret et al., 2009, 2012). Original descriptions by Agassiz (1843) placed the megatoothed sharks within the Lamnidae, however they have since been reclassified as the Otodontidae by Glikman (1964) to recognize their distinct evolutionary history. Since being formally described in the 1840s, the taxonomy of the otodontids has undergone a multitude of changes reflecting reinterpretations of their relationships by a host of researchers (see references above). It is beyond the scope of this study to address the taxonomic stability of the otodontid sharks, however we recognize the genera Otodus and Carcharocles for the lineage ending with Carcharocles megalodon. This arrangement stands in contrast with Glikman (1964) and Cappetta (2012), who both referred species with large lateral cusplets to Otodus, and those with small or no cusplets to the genus Megaselachus. Cappetta (2012) revised the taxonomy further, by separating the genus Otodus into three subgenera based on the presence, absence, or size of serrations and cusplets as well as differences in root morphology. Furthermore, Zhelezko and Kozlov (1999) separated many of the Otodus and Carcharocles species into subspecies (e.g., Otodus obliquus mugodzharicus and Otodus poseidoni poseidoni) based on specimens from Kazakhstan. These constructions only further complicate the taxonomy of the Otodontids and do little to elucidate the relationships of the megatoothed sharks. We also argue that, under a biological species concept, it is not possible to recognize subgenera and subspecies in the fossil record. Therefore, we reject these confusing and somewhat subjective designations. Otodontids do likely represent a chronospecific sequence, with individual species derived from a pattern of development that replaces one species with another sequentially through geologic time by incremental morphological and genetic changes (Applegate and Espinosa-Arrubarrena, 1996; Cappetta, 2012). This mechanism results in a descendant that is much different from its original ancestor, however when looking at smaller time intervals, species distinctions are much more difficult to discern. In the absence of a phylogenetic or a more thorough morphometric analysis, and until further work is conducted and published, we refer the unserrated form to Otodus obliquus and serrated forms to the genus Carcharocles.

Genus Carcharocles Jordan and Hannibal, 1923

Carcharocles auriculatus Blainville, 1818

Figures 3F-H, 4A-G, Table 1

Referred Specimens: ALMNH 1985.30.2, ALMNH 1985.35.2, ALMNH 1985.72.28.5, ALMNH 1985.72.33, ALMNH 1985.72.43.3, ALMNH 1985.72.55.2, ALMNH 1985.72.62.3, ALMNH 1985.72.83, ALMNH 1985.72.84, ALMNH 1985.72.88, ALMNH 1988.1.9, ALMNH 1988.29.1, ALMNH 1989.4.50.1, ALMNH 1992.28.44.1, ALMNH 1992.28.44.2, ALMNH 2000.1.4.1, ALMNH 2000.1.16.1, ALMNH 2000.1.27.1, ALMNH 2000.1.29.1, ALMNH 2000.1.33.1, ALMNH 2000.1.53, ALMNH 2000.1.57, ALMNH 2000.1.59, ALMNH 2005.6.259, ALMNH 2005.6.279, ALMNH 2005.6.294, ALMNH 2005.6.334.6, ALMNH 2005.6.407, ALMNH 2005.6.408.1, ALMNH 2010.5.3, MSC 20968, MSC 20969, MSC 20970, MSC 20971, MSC 20972, MSC 20973, MSC 20974, MSC 20975, MSC 20976, MSC 20977, MSC 20978, 
184 MSC 34422, MSC 34423, RMM 2370, RMM 2371

\section{Occurrence}

186 Choctaw, Clarke, Covington, Washington, and Wilcox counties, Alabama

\section{Description}

188 Characters used to identify $C$. auriculatus in this study include: a large, triangular crown

189 with the presence of lateral, serrated cusplets; serrated cutting edges that are fairly coarse and

190 irregular; presence of a v-shaped chevron on the lingual surface of the crown; and developed

191 lingual protuberance on the root. Remains of Carcharocles auriculatus are much more prevalent

192 in Alabama than those of Otodus obliquus. This difference is likely related to the fact that

193 Middle-Late Eocene deposits are much more expansive in Alabama than are sediments of the

194 Paleocene and Early Eocene.

195

196

197

198

199

200

201

202

203

204

205

206

207

208

209

210

211

212

213

214

215

216

217

218

219

220

221

222

223

224

225

226

In the ALMNH collections, 30 specimens of $C$. auriculatus were identified (Fig. 4A, E-G, Table 1). These teeth were collected from Choctaw, Clarke, Covington, Washington, and Wilcox counties in Alabama. Most of the teeth in the ALMNH collections were found in the Yazoo Clay of the Jackson Group and are Priabonian in age. Outcrops of the Yazoo Clay are prevalent throughout the western portion of Alabama and are well known for their marine fossils including early cetaceans such as Basilosaurus, Zygorhiza, and Cynthiacetus (Uhen, 2013). One specimen each of $C$. auriculatus was collected in the Lisbon Formation and the Gosport Sand, which are Lutetian and Bartonian in age, respectively.

Twenty-two C. auriculatus specimens were identified in the MSC collections. (Fig. 4B-D, $\mathrm{H}$, Table 1). A majority (17) of these teeth were collected from a single locality called Point A Dam in Covington County. Outcrops at this locality represent the boundary of the Tallahatta and Lisbon formations (middle Lutetian; Clayton et al., 2013). The remaining specimens were recovered from the Bartonian Gosport Sand in Choctaw County and the Priabonian Pachuta Marl Member of the Yazoo Clay of Washington County.

One specimen in the collections at MSC (MSC 34423; Fig. 3F) bears resemblance to the Late Paleocene - Early Eocene Otodus aksuaticus (Menner, 1928). Here, we define $O$. aksuaticus as specimens that exhibit triangular lateral cusplets; a triangular cusp; coarse serrations that fine towards the apex of the cusp; a v-shaped chevron; and a strong lingual protuberance of the root. This species is considered to be part of the chronospecies sequence between O. obliquus and C. auriculatus (Zhelezko and Kozlov, 1999) as it exhibits a transition from the unserrated $O$. obliquus to the serrated $C$. auriculatus, by means of coarse, irregular serrations that do not continue to the apex of the crown. This pattern of serration acquisition is very similar to that seen in the transition from Carcharodon hastalis to Carcharodon carcharias via Carchardon hubbelli, with coarser serrations at the base of the crown, fining towards the apex (Ehret et al., 2012).

MSC 34423 is here referred to C. auriculatus as it was discovered in sediments located at the Middle Eocene (Lutetian) boundary between the Lisbon and Tallahatta formations in Choctaw County. This specimen does exhibit coarse serrations that fine towards the apex of the cusp and might be close to O. aksuaticus, but we refer it here to $C$. auriculatus based on its Lutetian age. MSC 34423 represents a lateral tooth with a crown height of $18.8 \mathrm{~mm}$ and a crown width of $14.5 \mathrm{~mm}$. The tooth has an average of 1.2 serrations per $\mathrm{mm}$ on both anterior and distal cutting edges. 
Two other specimens in the ALMNH collections, ALMNH 1992.28.44.1 and ALMNH 1992.28.44.2 (Fig. 3G-H), we also refer to C. auriculatus, however they demonstrate more coarse serrations that fine towards the apex as seen in the earlier $O$. aksuaticus. The specimens are also Lutetian in age, having been collected at the boundary between the Lisbon and Tallahatta formations in Covington County, Alabama. Both teeth have broken apices and average 1.2 serrations per mm on their cutting edges. Although we assign all three of the aforementioned teeth to C. auriculatus, based on their similar morphology, we think there is a good potential for also finding $O$. aksuaticus in Alabama.

One partial vertebral centrum, MSC 20968 (Fig. 4H), recovered from the Point A Dam locality in Covington County, is also referred to C. auriculatus. The partial specimen (representing approximately one half of the centrum) is approximately $11.2 \mathrm{~cm}$ in diameter and $3.9 \mathrm{~cm}$ in thickness. The centrum is typically lamniform in appearance, laterally compressed with concave articular surfaces and radiating calcified lamellae within the intermedialia. Only one pit is preserved for the insertion of either the neural or haemal arch, however the centrum is fragmentary and it cannot be deduced as whether or not it is dorsal or ventral. We are confident in referring this specimen to $C$. auriculatus because of its lamniform appearance, age, and large size. Other lamniform taxa recovered from the Point A Dam locality are primarily odontaspids (Clayton et al., 2013), which would not have centra this large. For example, Hansen et al. (2013) reported a $6^{\text {th }}$ vertebral centrum diameter of $30 \mathrm{~mm}$ for a recent Odontaspis ferox specimen with a total body length of $297 \mathrm{~cm}$, which is significantly smaller than our fossil specimen.

\section{DISCUSSION}

248 Surprisingly, the presence of otodontid sharks in Alabama has not been extensively 249 reported in the literature. Agassiz (1843) noted the presence of Otodus crassa in Alabama, 250 although he provided no additional details. Leriche (1926) synonymized $O$. crassa with 251 Carcharodon hastalis, which is probably correct for some of the specimens figured in Agassiz 252 (1843). However, the Miocene $C$. hastalis has not been reported from Alabama and at least one 253 of the specimens figured in Agassiz (1843) appears to be O. obliquus. As a result, it stands to 254 reason that Agassiz (1843) might have been the first researcher to identify O. obliquus from 255 Alabama. A few years later, Gibbes (1848) described the presence of Otodus crassus within the 256 Cretaceous of Alabama. Describing what appears to be Carcharocles auriculatus, Gibbes, like 257 many researchers at the time, mistakenly referred the Eocene deposits in the state to the Upper 258 Cretaceous (Ebersole and Dean, 2013). Since that time, however, no other Otodus teeth are 259 known to have been reported in Alabama. As discussed above, many of the Otodus teeth in the 260 GSA collections were misidentified as Odontaspis, Lamna, or Carcharias, which could have 261 confounded the situation. Furthermore, outcrops of the Midway and Wilcox groups are not 262 widely exposed in Alabama, making it difficult to find Paleocene and Early Eocene fossils. 263 Another large $O$. obliquus specimen was observed by one of the authors in the collection of a 264 private collector; unfortunately this specimen could not be secured for the ALMNH collections at 265 the present time (D. Ehret, pers. observ.). Otodus specimens have also been found in nearby 266 states including the Williamsburg Formation of South Carolina (Purdy, 1998) and the Tuscahoma 267 Formation of Mississippi (Case, 1994). These discoveries leads us to propose that Otodus teeth 268 might be more prevalent in Alabama than previously thought if the proper aged outcrops are 269 targeted for collecting.

270 Carcharocles auriculatus is the megatoothed species that is more commonly found in 271 Alabama. Its predominance is likely a result of the comparably numerous outcrops of the Eocene 
272 Tallahatta and Lisbon formations and the Yazoo Clay. The large size of the teeth is also likely a

273 factor in their discovery and collection. The closely related Carcharocles angustidens was

274 reported from Alabama by White (1956) and Thurmond and Jones (1981). The specimens

275 discussed in White (1956) that are housed in the British Museum (NHM London) are referred to

276 the Jackson Group and, based on specimens discussed and figured here, are most likely $C$.

277 auriculatus. Thurmond and Jones (1981) figured a specimen (Fig. 22, pg. 56) referred to $C$.

278 angustidens as a line drawing, which was reported as being part of the former Birmingham

279 Southern College collections and collected from an unknown locality. Unfortunately the

280 whereabouts of this specimen are unknown, and the poor quality of the figure does not allow for

281 an accurate identification. $C$. angustidens is a species of otodontid recorded from the Oligocene

282 that exhibits a larger overall tooth size, smaller cusplets, and finer serrations than C. auriculatus.

283 Because there are relatively few Oligocene outcrops in Alabama and the relatively high

284 prevalence of Eocene outcrops, we are confident that all records of Carcharocles in Alabama

285 thus far represent $C$. auriculatus. Furthermore, prospecting Oligocene sediments in Alabama by

286 both authors has only yielded small to microscopic chondrichthyan teeth of Carcharhiniformes,

287 Ginglymostomatidae, and Myliobatidae. No occurrences of Carcharocles chubutensis or

288 Carcharocles megalodon have been accurately reported from Alabama, likely a result of the

289 historic lack of systematic collecting in the Mio-Pliocene formations in the state. However more

290 concentrated collecting efforts in southern Alabama where Oligocene-Pleistocene deposits are

291 more concentrated may yield new specimens. Additionally, the use of historic collections (e.g.,

292 the Geological Survey of Alabama collections) can be a valuable resource in identifying

293 overlooked or misidentified specimens.

\section{CONCLUSIONS}

295 The fossil record of otodontid sharks in Alabama has gone largely unreported in the

296 literature. Reviews of the collections at the Alabama Museum of Natural History, McWane

297 Science Center, and the Geological Survey of Alabama have yielded late Paleocene through

298 Eocene otodontids including O. obliquus and C. auriculatus from the state. This study represents

299 the first reliable report of Otodus from Alabama, with specimens identified from multiple

300 localities. Otodus obliquus was identified in the collections at the Geological Survey of Alabama,

301 most of which were collected prior to 1910. Based on observations of amateur collections, we

302 think that the presence of $O$. obliquus is likely more common than what the few specimens in

303 museum collections suggest. $C$. auriculatus is the most common otodontid shark recovered in

304 Alabama, typically recovered from Lutetian-Ypresian outcrops in southwestern Alabama. While

305 large specimens are not as common as they were 50-100 years ago, teeth assigned to this taxon

306 are still recovered with some regularity. We also refute Thurmond and Jones' (1981) report of $C$.

307 angustidens from the state. This specimen was most likely $C$. auriculatus, however, its status is

308 unknown until the tooth can be rediscovered. C. chubutensis and C. megalodon are currently not

309 known from Alabama, but with increased collection in the southern Cenozoic deposits in the

310 state, specimens might be recovered.

\section{Acknowledgements}

312 Many thanks to Sandy Ebersole, Geological Survey of Alabama, for access to the fossil

313 collections and help compiling the geologic data for Figure 1. The authors would also like to

314 thank Dave Cicimurri, South Carolina Museum of Natural History, and Chuck Ciampaglio, 
315 Wright State University, for useful discussions on otodontid records. We would also like to thank

316 the reviewers of this manuscript.

\section{REFERENCES}

318 Agassiz LJR. 1833-1844. Recherches sur les poisons fossils. Text (5 vols; I. xlix + 188 pp., II xii $+310+366$ pp., III viii + 390 pp., IV XVI + 296 pp., V xii + $122+160$ pp.) and Atlas. Neuchâtel, Imprimerie de Petitpierre.

Applegate SP, Espinosa-Arrubarrena L. 1996. The fossil history of Carcharodon and its possible ancestor, Cretolamna: a study in tooth identification. In: Klimley A, Ainley D, eds. Great White Sharks: the Biology of Carcharodon carcharias. San Diego: Academic Press, 19-36.

Berg S. 1958. System der rezenten und fossilen Fischgartigen und Fische. Berlin: Deutsche Verlag Wissenschaften.

Bieler R, Dockery III DT. 2007. Recognition of the Paleocene gastropods "Solariella" alabamensis (Aldrich, 1886) as a member of lower heterobranchs (Mathildidae), with description of Toulminella n. gen. Paläontologische Zeitschrift 81(3):283-290.

Blainville HMD de. 1818. Prodrome d'une distribution systematique du regne animal. Bulletin des Sciences pars la Société Philomathique de Paris 8:105-124.

Bonaparte CL. 1838. Selachorum tabula analytica. Nuovi Annali della Science Naturali, Bologna 2:195-214.

Cappetta H. 1987. Chondrichthyes II. Mesozoic and Cenozoic Elasmobranchii. In: Schultze HP, ed. Handbook of Paleoichthyology Volume 3B. New York: Verlag Dr. Gustav Fischer, 1-193.

Cappetta H. 2012. Chondrichthyes. Mesozoic and Cenozoic Elasmobranchii: Teeth. In: Schultze HP, ed. Handbook of Paleoichthyology Volume 3E. Munich: Verlag Dr. Gustav Fischer, 1512.

Clayton AA, Ciampagalio CN, Cicimurri, DJ. 2013. An inquiry into the stratigraphic occurrence of a Claibornian (Eocene) vertebrate fauna from Covington County, Alabama. Bulletin of the Alabama Museum of Natural History 31(2):60-73.

Ebersole JA, Dean LS. 2013. The history of Late Cretaceous vertebrate research in Alabama. Bulletin of the Alabama Museum of Natural History 31(1):3-45.

Ehret DJ, Hubbell G, MacFadden BJ. 2009. Exceptional preservation of the white shark Carcharodon (Lamniformes, Lamnidae) from the early Pliocene of Peru. Journal of Vertebrate Paleontology 29(1):1-13.

Ehret DJ, MacFadden BJ, Jones DS, DeVries TJ, Foster DA, Salas-Gismondi R. 2012. Origin of the white shark Carcharodon (Lamniformes: Lamnidae) based on recalibration of the upper Neogene Pisco Formation of Peru. Palaeontology 55(6):1139-1153.

Garner J, Bowles E. 1939. The Venericardia planicosta Group in the Gulf Province. Geological Survey Professional Paper 189-F:143-215.

Geological Survey of Alabama. 2006. Geologic map of Alabama Digital Version 1.0. Alabama Geological Survey Special Map 220A. Geological Survey of Alabama, Tuscaloosa, Alabama [adapted from Szabo, et al., 1988].

Gibbes RW. 1848. Monograph of the fossil Squalidae of the United States. Journal of the Academy of Natural Sciences of Philadelphia 7:191-206.

Glikman LS. 1964. Sharks of the Paleogene and their stratigraphic significance. Moscow: Nakua Press, Moscow. [In Russian]

Hansen BB, Cuny G, Rasmussen BW, Shimada K, Jacobs P, Heilman-Clausen C. 2013. Associated skeletal and dental remains of a fossil odontaspid shark (Elasmobranchii: 
376

377

378

379

380

381

382

383

384

385

386

387

388

389

390

391

392

393

394

395

396

397

398

399

400

401

Lamniformes) from the Middle Eocene Lillebælt Clay Formation in Denmark. Bulletin of the Geological Society of Denmark 61:37-46.

Huxley TH. 1880. A manual of the anatomy of vertebrated animals, D. New York: Appleton.

Johnson CW. 1932. Truman Hemingway Aldrich. The Nautilis 46(1):34-35.

Jordan DS, Hannibal H. 1923. Fossil sharks and rays of the Pacific Slope of North America. Bulletin of the Southern California Academy of Sciences 22:27-63.

Keroher GC et al., 1966. Lexicon of geologic names of the United States for 1936-1960. U.S. Geological Survey Bulletin 1200, 3 parts, 4,341 p.

Leriche M. 1926. Les poisons Néogènes de la Belgique. Mémoires de Museé Royal du d'Histoire Naturelle de Belgique 32:367-472.

Mancini EA, Tew BH. 1988. Paleocene sequence Stratigraphy of southwestern Alabama. Gulf Coast Association of Geological Societies Transactions 38:453-460.

Mancini EA, Tew BH. 1991. Relationships of Paleogene state and planktonic foraminiferal zone boundaries to lithostratigraphic and allostratigraphic contacts in the eastern Gulf Coastal Plain. Journal of Foraminiferal Research 21(1):48-66.

Menner VV. 1928. The Palaeogene sharks of Mangyschlak, Emba and from the east of Oural. Bulletin de la Société des Naturalistes de Moscou Section, Géologique 6(3-4): 291-338. [In Russian]

Nolf D, Dockery III DT. 1993. Fish otoliths from the Matthews Landing Marl Member (Porters Creek Formation), Paleocene of Alabama. Mississippi Geology 14(2):24-39.

Nyberg KG, Ciampaglio CN, Wray GA. 2006. Tracing the ancestry of the great white shark, Carcharodon carcharias, using morphometric analyses of fossil teeth. Journal of Vertebrate Paleontology 26:806-814.

Pimiento C, Ehret DJ, MacFadden BJ, Hubbell G. 2010. Ancient nursery area for the extinct giant shark Megalodon from the Miocene of Panama. PLoS One 5(5): e10552.

Pimiento C, Gonzalez-Barba G, Hendy AJW, Jaramillo C, MacFadden BJ, Montes C, Suarez SC, Shippritt M. 2013. Early Miocene chondrichthyans from the Culebra Formation, Panama: A window into marine vertebrate faunas before closure of the Central American Seaway. Journal of South American Earth Sciences 42: 159-170.

Purdy R. 1998. Chondrichthyan fishes from the Paleocene of South Carolina. In: Sanders AE, ed. Paleobiology of the Williamsburg Formation (Black Mingo Group; Paleocene) of South Carolina, U.S.A. Transactions of the American Philosophical Society Vol. 88, Pt. 4:122-146. Purdy R, Schneider VP, Applegate SP, McLellan JH, Meyer RL, Slaughter BH. 2001. The Neogene sharks, rays, and bony fishes from Lee Creek Mine, Aurora, North Carolina. In: Ray CE, Bohaska DJ, eds. Geology and Paleontology of the Lee Creek Mine, North Carolina, III. Smithsonian Contributions to Paleobiology no. 90: 71-202.

Raymond DE, Osborne WE, Copeland CW, Neathery TL. 1988. Alabama Stratigraphy. Geological Survey of Alabama Circular 140. 97 pp.

Smith EA, Johnson LC. 1887. Tertiary and Cretaceous strata of the Tuscaloosa, Tombigbee, and Alabama Rivers. Bulletin of the United States Geological Survey 43:1-189.

Szabo MW, Osborne WE, Copeland CW, Jr., Neathery TL. 1988. Geologic map of Alabama (1:250,000): Alabama Geological Survey Special Map 220, Tuscaloosa. 
402 Thurmond JT, Jones DE. 1981. Fossil vertebrates of Alabama. Tuscaloosa: University of 403 Alabama Press.

404 Toulmin LD. 1977. Stratigraphic Distribution of Paleocene and Eocene Fossils in the Eastern 405 Gulf Coast Region, Volume I. Geological Survey of Alabama Monograph 13, 602 pp.

406 Uhen MD. 2013. A review of North American Basilosauridae. Alabama Museum of Natural $407 \quad$ History Bulletin 31 (2): 1-45.

408 White EI. 1956. The Eocene fishes of Alabama. Bulletins of American Paleontology, 36 (156): 409 123-150.

410 Zhelezko V, Kozlov V. 1999. Elasmobranchii and Paleogene biostratigraphy of Transurals and 411 Central Asia. Materials on stratigraphy palaeontology of the Urals, Vol. 3. Russian Academy 412 of Sciences, Urals Branch, Uralian Regional Interdepartment Stratigraphical Commission, $413 \quad$ Yekaterinburg, $324 \mathrm{pp}$. 
Figure 1

Geologic map of Paleocene and Eocene strata in Alabama

Map showing Paleocene and Eocene strata in Alabama and known collecting localities for Otodontid specimens. County abbreviations: Br, Barbour; Bt, Butler; Cc, Conecuh; Cf, Coffee; Ch, Choctaw; Ck, Clarke; Cn, Crenshaw; Cv, Covington; Da, Dallas; DI, Dale; Es, Escambia; Ge, Greene; Hn, Henry; Hs, Houston; Lw, Lowndes; Mg, Marengo; Mn, Monroe; Pk, Pike; Su, Sumter; Ws, Washington, and Wx, Wilcox. Compiled using Geological Survey of Alabama digital geology data (GSA, 2006). 


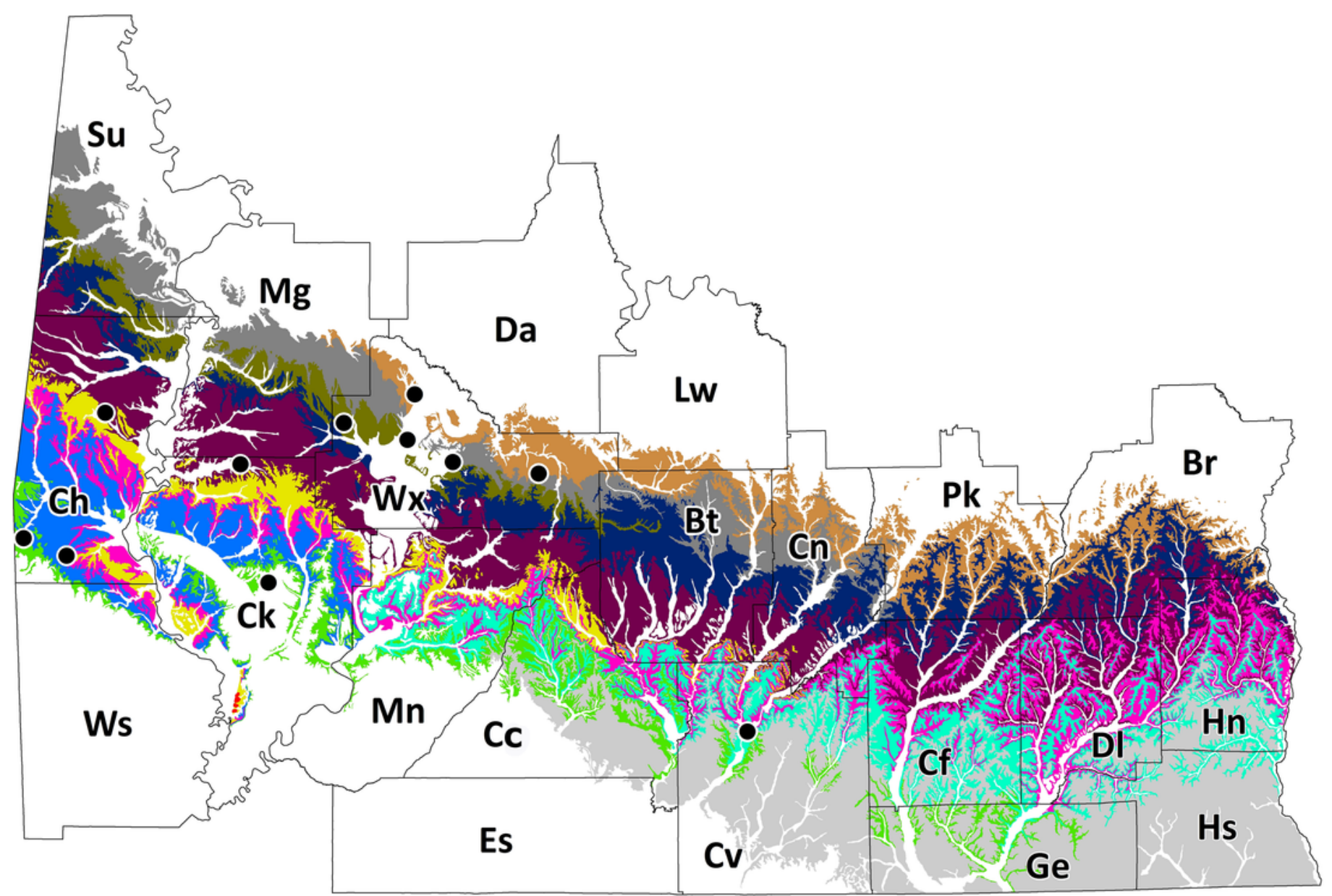

\section{0 miles}

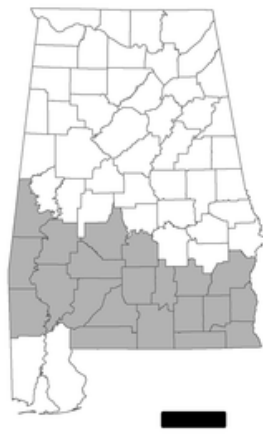

Legend

\section{Paleocene}

Tuscahoma Sand
Nanafalia Formation
Salt Mountain Limestone
Naheola Formation
Porters Creek Formation
Clayton Formation

Eocene-Oligocene

Residuum

\section{Eocene}

Jackson Group undifferentiated

Gosport Sand and Lisbon undiff.

Lisbon Formation

Tallahatta Formation

Hatchetigbee Formation

50 miles 
Figure 2

Paleocene and Eocene Stratigraphy of Alabama

Stratigraphic chart showing the age of Paleocene and Eocene formations of Alabama.

Modified from Mancini and Tew (1991). 


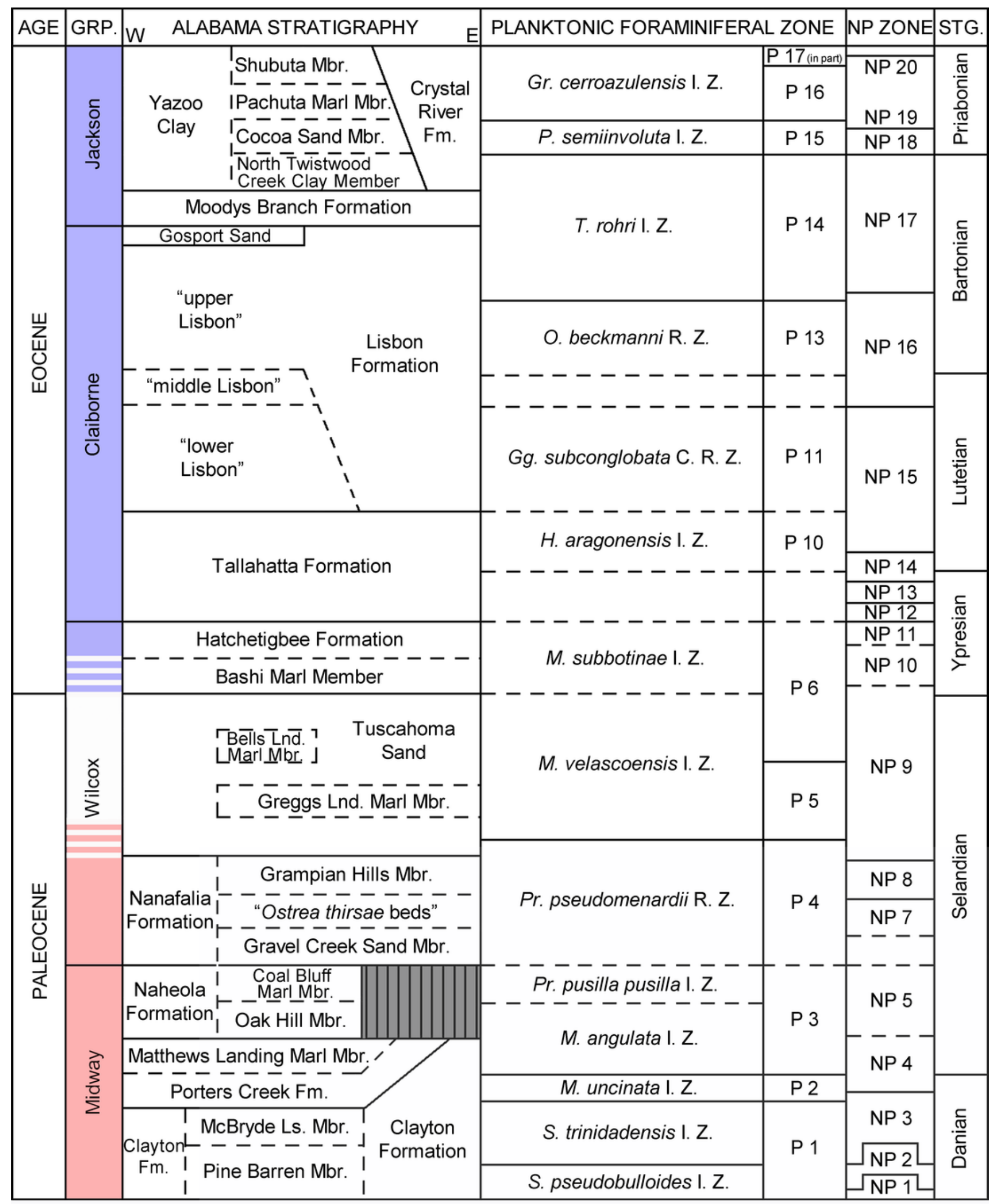

Range of Otodus obliquus in Alabama
Range of Carcharocles auriculatus in Alabama 
Figure 3

Otodus obliquus and Carcharocles auriculatus teeth from Alabama

Otodus obliquus specimens from Alabama. Labial view on left, lingual view on right. A) GSA

CZ 5051, Unknown formation; B) GSA CZ 5050, Matthews Landing Marl Mbr.; C) GSA CZ 5052, Matthews Landing Marl Mbr.; D) GSA CZ 5053, Porters Creek Fm. E) GSA CZ 5054, Midway Group; Carcharocles auriculatus specimens, labial view on left, lingual view on right.

F) MSC 34423, Lisbon-Tallahatta fms.; F) ALMNH 1992.28.44.1, Lisbon-Tallahatta fms.; G) ALMNH 1992.28.44.2, Lisbon-Tallahatta fms. Scale Bar $=5 \mathrm{~cm}$. 

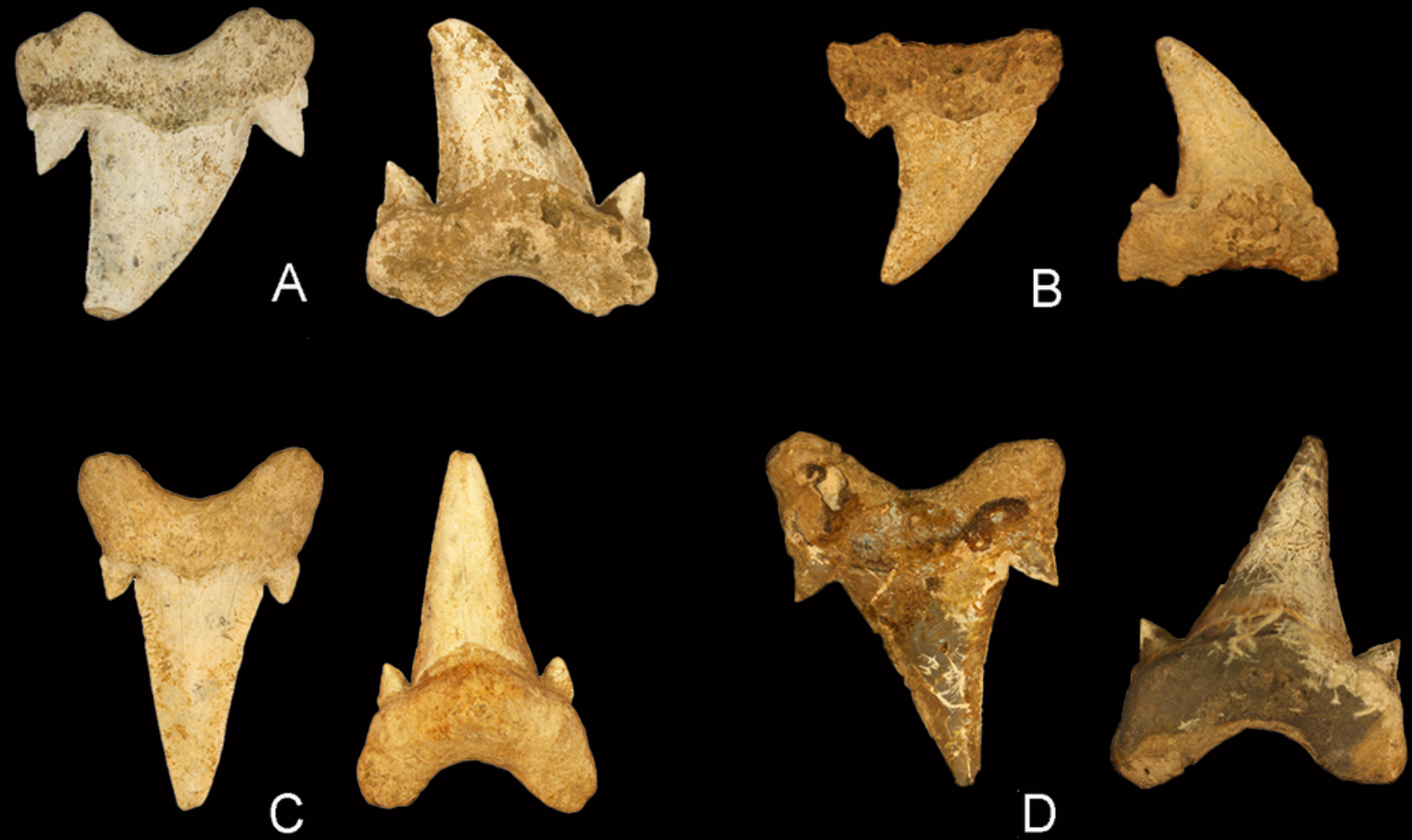

D
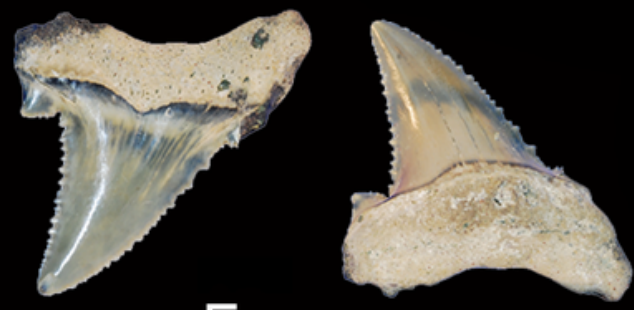

E

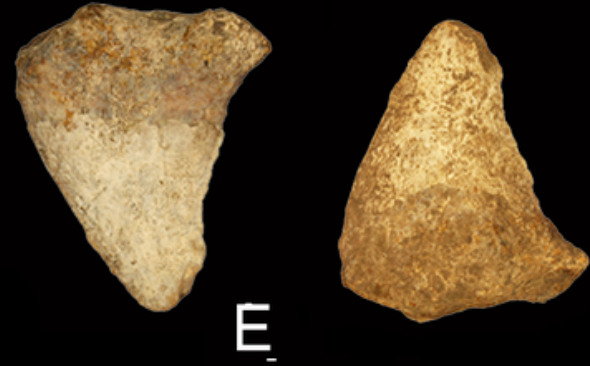

F
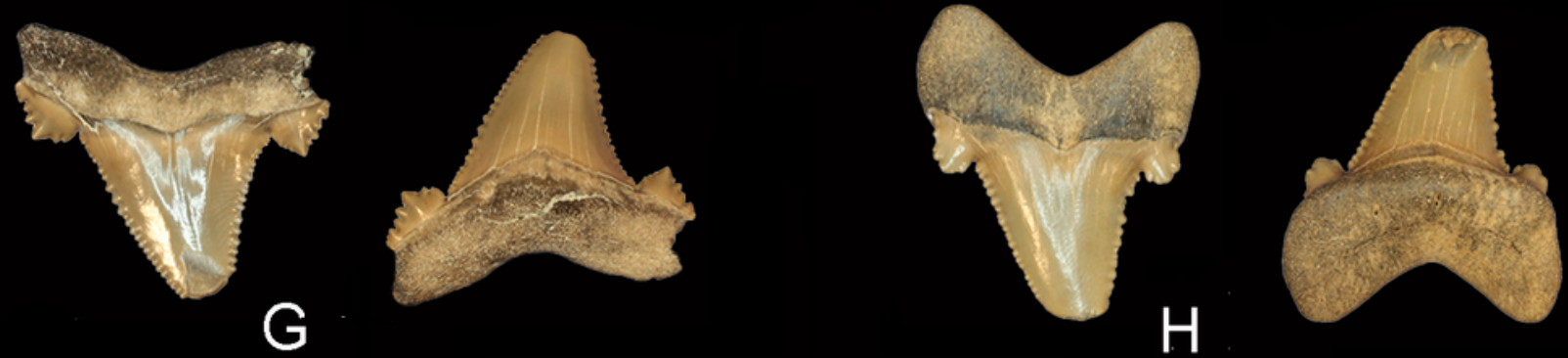

$\mathbf{G}$

$\mathrm{H}$ 
Figure 4

Carcharocles auriculatus teeth from Alabama

Carcharocles auriculatus specimens from Alabama. Labial view on left, lingual view on right. A) ALMNH 1988.29.1, Hatchetigbee Fm.; B) MSC 20970, Lisbon-Tallahatta Fms.; C) MSC 20973, Lisbon-Tallahatta Fms.; D) RMM 2371, Gosport Sand; E) ALMNH 2000.1.29.1, Yazoo Clay; F) ALMNH 2000.1.33.1, Yazoo Clay; G) ALMNH 2005.6.294, Unknown formation; H) MSC 20968, Lisbon-Tallahatta Fm. Scale Bar $=5 \mathrm{~cm}$. 
PeerJ Reviewing Manuscript
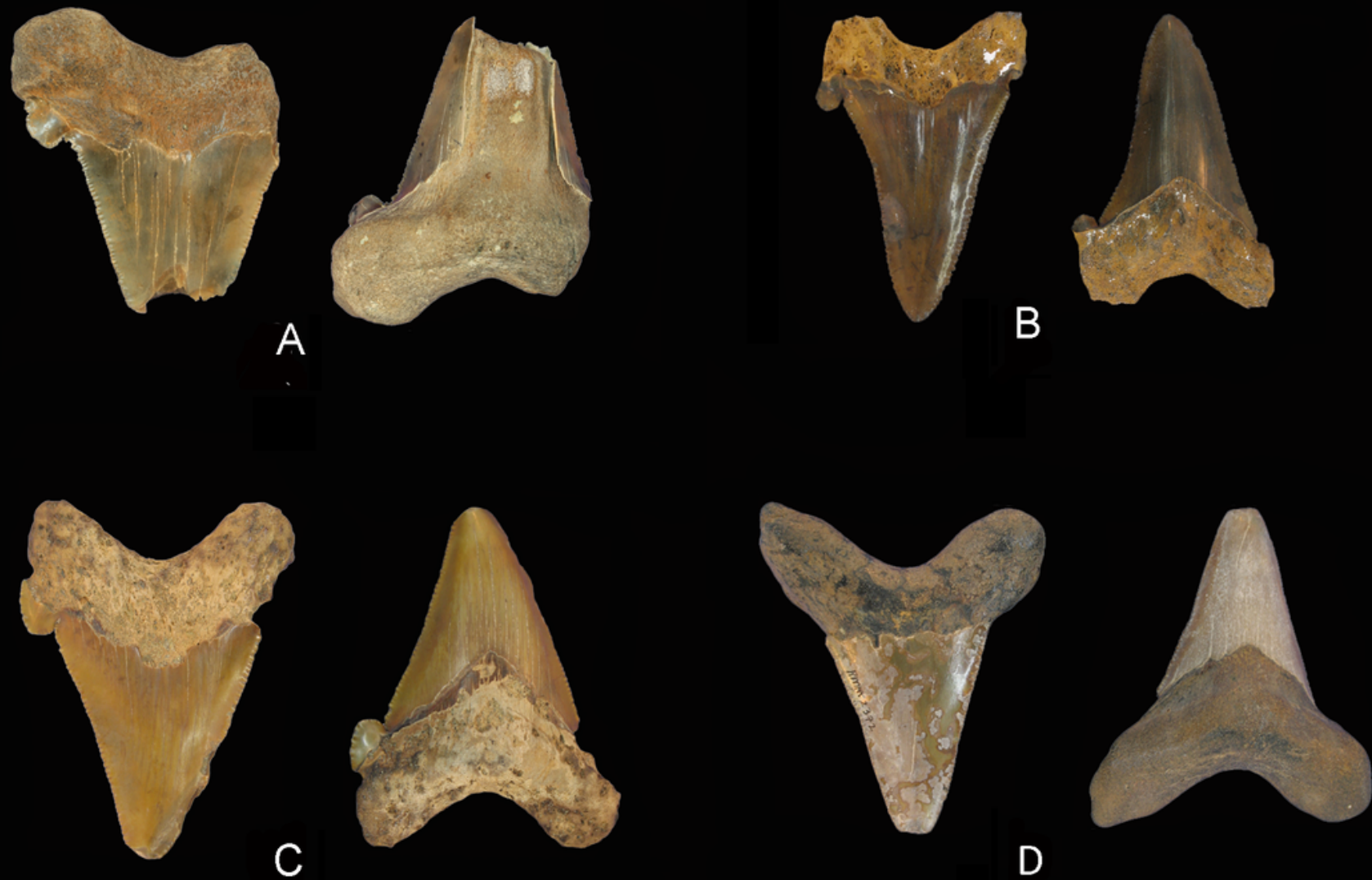

D
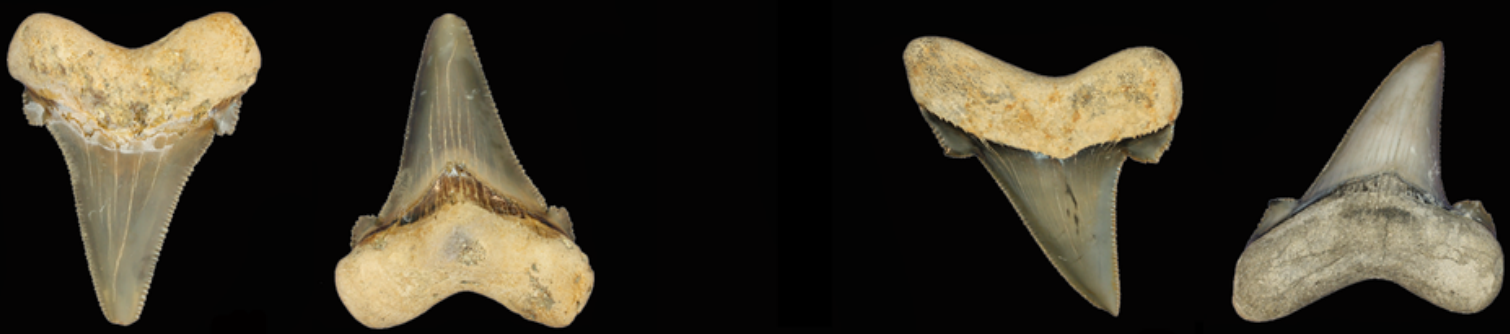

E

F
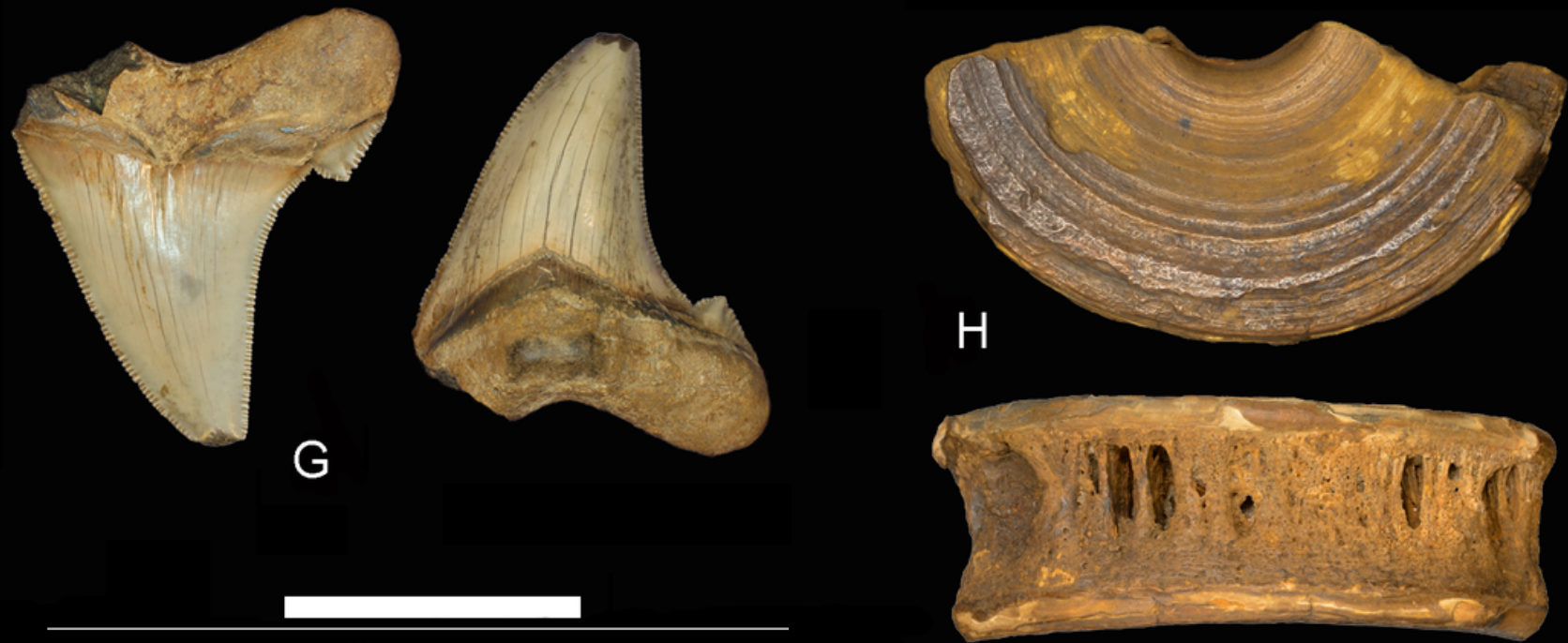
Table $\mathbf{1}$ (on next page)

Otodus and Carcharocles specimens in museum collections from Alabama

Otodus and Carcharocles specimens from the Alabama Museum of Natural History (ALMNH), Geological Survey of Alabama (GSA), and McWane Science Center collections (MSC/RMM). 


\begin{tabular}{|c|c|c|c|c|c|c|c|}
\hline Catalog/Accession Number & Genus & Species & Formation/Unit & Stage & County & State & Locality \\
\hline ALMNH 1985.30.2 & Carcharocles & auriculatus & Unknown & Unknown & Unknown & $\mathrm{AL}$ & Unknown \\
\hline ALMNH 1985.35.2 & Carcharocles & auriculatus & Unknown & Unknown & Unknown & $\mathrm{AL}$ & Unknown \\
\hline ALMNH 1985.72.28.5 & Carcharocles & auriculatus & Hatchetigbee or Lisbon Fm. & $\begin{array}{l}\text { Ypresian or } \\
\text { Lutetian/Bartonian }\end{array}$ & Choctaw & $\mathrm{AL}$ & Shell Creek \\
\hline ALMNH 1985.72 .33 & Carcharocles & auriculatus & Unknown & Unknown & Unknown & $\mathrm{AL}$ & Unknown \\
\hline ALMNH 1985.72.43.3 & Carcharocles & auriculatus & Unknown & Unknown & Unknown & $\mathrm{AL}$ & Unknown \\
\hline ALMNH 1985.72.55.2 & Carcharocles & auriculatus & Unknown & Unknown & Unknown & $\mathrm{AL}$ & Unknown \\
\hline ALMNH 1985.72.62.3 & Carcharocles & auriculatus & Unknown & Unknown & Unknown & $\mathrm{AL}$ & Unknown \\
\hline ALMNH 1985.72 .83 & Carcharocles & auriculatus & Unknown & Unknown & Unknown & $\mathrm{AL}$ & Unknown \\
\hline ALMNH 1985.72 .84 & Carcharocles & auriculatus & Unknown & Unknown & Unknown & $\mathrm{AL}$ & Unknown \\
\hline ALMNH 1985.72 .88 & Carcharocles & auriculatus & Unknown & Unknown & Unknown & $\mathrm{AL}$ & Unknown \\
\hline ALMNH 1988.1.9 & Carcharocles & auriculatus & Yazoo Clay & $\begin{array}{l}\text { Bartonian/Priabonia } \\
\mathrm{n}\end{array}$ & Unknown & $\mathrm{AL}$ & Unknown \\
\hline ALMNH 1988.29.1 & Carcharocles & auriculatus & Gosport Sand & Bartonian & Choctaw & $\mathrm{AL}$ & Puss Cuss Creel \\
\hline ALMNH 1989.4.50.1 & Carcharocles & auriculatus & Lisbon Fm. & Lutetian/Bartonian & Choctaw & $\mathrm{AL}$ & Butler \\
\hline ALMNH 1992.28.44.1 & Carcharocles & auriculatus & Lisbon-Tallahatta Contact & Lutetian & Covington & $\mathrm{AL}$ & Point-A Dam \\
\hline ALMNH 1992.28.44.2 & Carcharocles & auriculatus & Lisbon-Tallahatta Contact & Lutetian & Covington & $\mathrm{AL}$ & Point-A Dam \\
\hline ALMNH 2000.1.4.1 & Carcharocles & auriculatus & Yazoo Clay & $\begin{array}{l}\text { Bartonian/Priabonia } \\
\mathrm{n}\end{array}$ & Choctaw & $\mathrm{AL}$ & Unknown \\
\hline ALMNH 2000.1.16.1 & Carcharocles & auriculatus & Yazoo Clay & $\begin{array}{l}\text { Bartonian/Priabonia } \\
\mathrm{n}\end{array}$ & Choctaw & $\mathrm{AL}$ & Unknown \\
\hline ALMNH 2000.1.27.1 & Carcharocles & auriculatus & Yazoo Clay & $\begin{array}{l}\text { Bartonian/Priabonia } \\
\mathrm{n}\end{array}$ & Choctaw & $\mathrm{AL}$ & Unknown \\
\hline ALMNH 2000.1.29.1 & Carcharocles & auriculatus & Yazoo Clay & $\begin{array}{l}\text { Bartonian/Priabonia } \\
\mathrm{n}\end{array}$ & Choctaw & $\mathrm{AL}$ & Unknown \\
\hline ALMNH 2000.1.33.1 & Carcharocles & auriculatus & Pachuta Marl Member & Priabonian & Washington & $\mathrm{AL}$ & Bashi \\
\hline ALMNH 2000.1.53 & Carcharocles & auriculatus & Yazoo & $\begin{array}{l}\text { Bartonian/Priabonia } \\
\mathrm{n}\end{array}$ & Choctaw & $\mathrm{AL}$ & Unknown \\
\hline ALMNH 2000.1.57 & Carcharocles & auriculatus & Yazoo & $\begin{array}{l}\text { Bartonian/Priabonia } \\
\mathrm{n}\end{array}$ & Choctaw & $\mathrm{AL}$ & Unknown \\
\hline ALMNH 2000.1.59 & Carcharocles & auriculatus & Yazoo & $\begin{array}{l}\text { Bartonian/Priabonia } \\
\mathrm{n}\end{array}$ & Choctaw & $\mathrm{AL}$ & Unknown \\
\hline ALMNH 2005.6.259 & Carcharocles & auriculatus & Yazoo Clay & $\begin{array}{l}\text { Bartonian/Priabonia } \\
\mathrm{n}\end{array}$ & Choctaw & $\mathrm{AL}$ & Unknown \\
\hline ALMNH 2005.6.279 & Carcharocles & auriculatus & Yazoo Clay & $\begin{array}{l}\text { Bartonian/Priabonia } \\
\mathrm{n}\end{array}$ & Clarke & $\mathrm{AL}$ & Grove Hill \\
\hline ALMNH 2005.6.294 & Carcharocles & auriculatus & Unknown & Unknown & Unknown & $\mathrm{AL}$ & Unknown \\
\hline ALMNH 2005.6.334.6 & Carcharocles & auriculatus & Tallahatta Fm. & Ypresian/Lutetian & Wilcox & $\mathrm{AL}$ & Prairie Bluff \\
\hline ALMNH 2005.6.407 & Carcharocles & auriculatus & Unknown & Unknown & Unknown & $\mathrm{AL}$ & Unknown \\
\hline ALMNH 2005.6.408.1 & Carcharocles & auriculatus & Unknown & Unknown & Wilcox & $\mathrm{AL}$ & Prairie Bluff \\
\hline ALMNH 2010.5.3 & Carcharocles & auriculatus & Unknown & Unknown & Unknown & $\mathrm{AL}$ & Unknown \\
\hline GSA 5050 & Otodus & obliquus & $\begin{array}{l}\text { Matthews Landing Marl } \\
\text { Member }\end{array}$ & Selandian & Wilcox & $\mathrm{AL}$ & Camden \\
\hline GSA 5051 & Otodus & obliquus & Unknown & Unknown & Wilcox & $\mathrm{AL}$ & Unknown \\
\hline GSA 5052 & Otodus & obliquus & $\begin{array}{l}\text { Matthews Landing Marl } \\
\text { Member }\end{array}$ & Selandian & Wilcox & $\mathrm{AL}$ & $\begin{array}{l}\text { Matthews } \\
\text { Landing }\end{array}$ \\
\hline GSA 5053 & Otodus & obliquus & Porters Creek Formation & Danian & Wilcox & $\mathrm{AL}$ & $\begin{array}{l}\text { Graveyard Hill } \\
\text { No. } 4\end{array}$ \\
\hline GSA 5054 & Otodus & obliquus & Midway Group & Danian/Selandian & Unknown & $\mathrm{AL}$ & Unknown \\
\hline MSC 20969 & Carcharocles & auriculatus & Lisbon-Tallahatta Contact & Lutetian & Covington & $\mathrm{AL}$ & Point-A Dam \\
\hline MSC 20970 & Carcharocles & auriculatus & Lisbon-Tallahatta Contact & Lutetian & Covington & $\mathrm{AL}$ & Point-A Dam \\
\hline MSC 20971 & Carcharocles & auriculatus & Lisbon-Tallahatta Contact & Lutetian & Covington & $\mathrm{AL}$ & Point-A Dam \\
\hline MSC 20972 & Carcharocles & auriculatus & Lisbon-Tallahatta Contact & Lutetian & Covington & $\mathrm{AL}$ & Point-A Dam \\
\hline MSC 20973 & Carcharocles & auriculatus & Lisbon-Tallahatta Contact & Lutetian & Covington & $\mathrm{AL}$ & Point-A Dam \\
\hline MSC 20974 & Carcharocles & auriculatus & Lisbon-Tallahatta Contact & Lutetian & Covington & $\mathrm{AL}$ & Point-A Dam \\
\hline MSC 20975 & Carcharocles & auriculatus & Lisbon-Tallahatta Contact & Lutetian & Covington & $\mathrm{AL}$ & Point-A Dam \\
\hline MSC 20976 & Carcharocles & auriculatus & Lisbon-Tallahatta Contact & Lutetian & Covington & $\mathrm{AL}$ & Point-A Dam \\
\hline MSC 20977 & Carcharocles & auriculatus & Lisbon-Tallahatta Contact & Lutetian & Covington & $\mathrm{AL}$ & Point-A Dam \\
\hline MSC 20978 & Carcharocles & auriculatus & Lisbon-Tallahatta Contact & Lutetian & Covington & $\mathrm{AL}$ & Point-A Dam \\
\hline MSC 20979 & Carcharocles & auriculatus & Lisbon-Tallahatta Contact & Lutetian & Covington & $\mathrm{AL}$ & Point-A Dam \\
\hline MSC 20980 & Carcharocles & auriculatus & Lisbon-Tallahatta Contact & Lutetian & Covington & $\mathrm{AL}$ & Point-A Dam \\
\hline MSC 20981 & Carcharocles & auriculatus & Lisbon-Tallahatta Contact & Lutetian & Covington & $\mathrm{AL}$ & Point-A Dam \\
\hline MSC 20982 & Carcharocles & auriculatus & Lisbon-Tallahatta Contact & Lutetian & Covington & $\mathrm{AL}$ & Point-A Dam \\
\hline MSC 20983 & Carcharocles & auriculatus & Lisbon-Tallahatta Contact & Lutetian & Covington & $\mathrm{AL}$ & Point-A Dam \\
\hline MSC 20984 & Carcharocles & auriculatus & Lisbon-Tallahatta Contact & Lutetian & Covington & $\mathrm{AL}$ & Point-A Dam \\
\hline MSC 20985 & Carcharocles & auriculatus & Lisbon-Tallahatta Contact & Lutetian & Covington & $\mathrm{AL}$ & Point-A Dam \\
\hline MSC 29068 & Carcharocles & auriculatus & Lisbon-Tallahatta Contact & Lutetian & Covington & $\mathrm{AL}$ & Point-A Dam \\
\hline MSC 34422 & Carcharocles & auriculatus & $\begin{array}{l}\text { Yazoo Clay - Pachuta Marl } \\
\text { Mbr. }\end{array}$ & Priabonian & Washington & $\mathrm{AL}$ & Unknown \\
\hline MSC 34423 & Carcharocles & auriculatus & Lisbon-Tallahatta Contact & Lutetian & Choctaw & $\mathrm{AL}$ & Silas \\
\hline RMM 2370 & Carcharocles & auriculatus & Gosport Sand & Bartonian & Choctaw & $\mathrm{AL}$ & Puss Cuss Creel \\
\hline RMM 2371 & Carcharocles & auriculatus & Gosport Sand & Bartonian & Choctaw & $\mathrm{AL}$ & Puss Cuss Creel \\
\hline
\end{tabular}

